\title{
Heuristic Evaluation of Three Jordanian University Websites
}

\author{
Layla HASAN \\ Department of Computer Information Systems, Zarqa University, Jordan \\ e-mail: l.hasan2@yahoo.co.uk
}

Received: April 2013

\begin{abstract}
Generally, universities have complex and large websites, which include a collection of many sub-sites related to the different parts of universities (e.g. registration unit, faculties, departments). Managers of academic institutions and educational websites need to know types of usability problems that could be found on their websites. This would shed the light on possible weak aspects on their websites, which need to be improved, in order to reap the advantages of usable educational websites. There is a lack of research which provides detailed information regarding the types of specific usability problems that could be found on universities' websites in general, and specifically in Jordan. This research employed the heuristic evaluation method to comprehensively evaluate the usability of three large public university websites in Jordan (Hashemite University, the University of Jordan, and Yarmouk University). The evaluation involves testing all pages related to the selected universities' faculties and their corresponding departments. A list of 34 specific types of usability problems, which could be found on a Jordanian university website, was identified. The results provide a description regarding the common types of the problems found on the three Jordanian university sites, together with their numbers and locations on the website.
\end{abstract}

Keywords: usability, heuristic evaluation, educational websites, Jordan.

\section{Introduction}

Usability is one of the most important characteristics of any user interface; it measures how easy the interface is to use (Nielsen, 2003). Usability has been defined as "the extent to which a product can be used by specified users to achieve specified goals with effectiveness, efficiency, and satisfaction in a specified context of use" (ISO 9241-11, 1998). Usability does not only evaluate the quality of a website, but also provide managers with insights into potential problem areas (Agarwal and Venkatesh, 2002).

Various usability evaluation methods have been developed to evaluate the usability of websites. The methods could be categorized into three categories, in terms of how the usability problems are identified, for example by evaluators, users, or tools. Evaluatorbased methods are aimed at finding usability problems that users might encounter while interacting with an interface, from the evaluators' point of view. Heuristic evaluation is one of the most frequently evaluator-based usability evaluation methods. It involves 
having a number of evaluators assess the user interface, and judge whether it conforms to a set of usability principles, namely heuristics, (Nielsen and Molich, 1990). The other usability evaluation methods, which involve users in the process of identifying usability problems, include observations, questionnaires, and interviews.

With the fast development of the Internet, the increasing use of www as an information-seeking, and the increasing number of educational websites, the importance of universities' websites increased. Academic institutions (e.g. universities, colleges) were among the early developers of websites to present themselves on the Internet (Astani and Elhindi, 2008; Sandvig and Bajwa, 2004; Peterson, 2006). However, the aim of their websites differed with time, due to the technological advances and the increasing number of Internet users. For example, in early 1990, university websites started as informational websites aiming simply to have a presence on the web (Peterson, 2006; Astani and Elhindi, 2008). Nowadays, academic websites become a vital part of academic institutions, and one of their most visible faces (Peterson, 2006). Therefore, the aim of the websites for the academic institutions changed. Research indicated that educational websites aim to:

- Recruit major stakeholders of academic institutions (e.g. prospective students, prospective faculty, alumni, parents) (Astani and Elhindi, 2008; Astani, 2003; Pierce, 2005).

- Provide effective services (e.g. email, virtual learning environment), and online communication for their other stakeholders.

- Provide a way to present their image on the Internet (e.g. academic offering, programs, services, students resources) (Astani and Elhindi, 2008; Astani, 2003; Mentes and Turan, 2012).

In order to achieve the mentioned aims, and to respond to the new generation of students whom grown up with technology, educational websites should consider usability while making and improving their websites. Addressing the usability of educational websites could help students to enjoy the learning experience, increase students' confidence, and encourage students to use the website (Lencastre and Chaves, 2008). Unfortunately, a university website design is often based on the perceptions of web designers, and/or managers in a university instead of students' needs. Furthermore, many website designers have little knowledge of user interface design and usability engineering, therefore, wasting users' time and causing unnecessary traffic on the Internet (Astani and Elhindi, 2008).

Despite the importance of making educational websites usable, few studies were found in the literature that evaluated the usability of such sites, specifically in the context of Arabic websites. The studies that were found employed usability methods, including heuristic evaluation, to evaluate the usability of educational websites (Astani and Elhindi, 2008; Noiwan and Norcio, 2000; Pierce, 2005; Kostaras and Xenos, 2006; Toit and Bothma, 2010). However, these studies did not provide details regarding specific types of usability problems that could be found on educational websites.

The aim of this research is to comprehensively investigate the usability of three university websites in Jordan, in order to identify common usability problem areas that could be found on Jordanian university websites. The specific objectives for the research are: 
- To use the heuristic evaluation approach to assess to what extent the three selected university websites have conformed to usability principles.

- To identify common usability problems that could be found on each Jordanian university website.

- To generate a list of common usability problem areas that could be found on a Jordanian university website.

This paper is presented as follows. Section two reviews related work. Section three describes the methods used. Section four outlines the main results. Section five discusses the results in light of the literature. Finally section six reviews and presents some conclusions.

\section{Literature Review}

This section provides an overview regarding related work. It is divided into two sections. The first concerns earlier research, which evaluated the usability of educational websites. The second reviews studies, which shed the light on preferable website features regarding usable educational websites from users' perspectives.

\subsection{Evaluating the Usability of Educational Websites}

This section reviews studies that evaluated the usability of educational sites. These studies employed various usability methods in the process of identifying usability problems. Astani and Elhindi (2008), for example, employed the heuristic evaluation method to evaluate the usability of the top 50 colleges and universities. The study was conducted by two experts who evaluated and rated the sites (based on Likert scale) against five characteristics: Information content, navigation, usability, customization, download speed and security. The authors indicated that the tested websites had usability problems related mainly to old content and inappropriate layout.

Noiwan and Norcio (2000) also evaluated and compared the usability of two Thai and two US academic websites, using web usability checklist that aimed to measure the usability indexes of the sites. The checklist was categorized into four major sections: Finding the information, understanding the information, supporting user tasks, and presenting the information. Each guideline of the checklist was presented as yes/no question. The results showed that the sites had several usability problems including: Lack of a site map, old content, lack of navigational tools, and inconsistency problems. The results also showed that the Thai websites have additional problems, such as: Ineffective internal search functions and language problems (e.g. misspelling words).

Similarly, Kostaras and Xenos (2006) employed the heuristic evaluation method to evaluate the usability of the website of the Hellenic Open University using the ten usability heuristics suggested by Nielsen et al. (1994). They identified only 38 usability problems on the university website related to: Lack of navigational support links, inconsistency problems (e.g. a variation of font sizes was used), errors in the internal search function, and inappropriate design of menu. 
Furthermore, Toit and Bothma (2010) investigated the usability of the website of an academic marketing department in the University of South Africa, using the heuristic evaluation method. They mentioned only few examples regarding the usability problems that were identified on the website, which related to: Poor navigation, old content, and incomplete information regarding the modules of the department.

Pierce (2005), however, employed heuristic evaluation, and user testing methods to evaluate the usability of Harvard University website. Nielsen et al. (1994)'s ten heuristics were used during the heuristic evaluation. The results identified some usability problems on the site, related mainly to: Lack of navigational tools, inconsistency problems, and inappropriate design of the home page.

Other studies were found in the literature which employed users in the evaluation and identification of usability problems on educational websites. Kasli and Aucikurt (2008), for example, employed 54 students to investigate 132 websites of tourism departments at universities in Turkey. The results showed that most of the sites: Did not present updated information, did not have an internal search function, did not present their content in foreign languages, and did not display important information (e.g. academic calendar, FAQ, programs).

Similarly, Christoun et al. (2006) investigated students' overall satisfaction with an academic website, with regard to its technology, usability, aesthetic, and content using an online questionnaire. The results showed that only $53.4 \%$ of the students agreed that the search function of the site was effective, and $66 \%$ agreed that it was easy to find information.

Few studies were found in the literature regarding Arabic websites. The study conducted by Mustafa and Al-Zoua'bi (2008) is an example. They employed a questionnaire to evaluate the usability of nine Jordanian university websites, by 252 students. The results showed that, although the overall usability level of the websites was acceptable, there were some weaknesses in some aspects of the sites (e.g. design, interface, performance). However, the study didn't provide details regarding specific types of usability problems that users identified on the university sites.

Similarly, Hasan (2012a) asked 237 students to provide ratings for nine Jordanian university websites using usability criteria. The criteria consisted of five categories: Navigation, architecture / organization, ease of use and communication, design, and content. The students were also asked to report qualitatively what they liked, and disliked regarding the design of the websites. The results showed that the common weaknesses on the websites include: The design of the sites, the fact that most of the sites were inconsistent, in terms of: Colors, fonts, the Arabic and English language interface, and the design of the pages, and the lack of support to Arabic language.

\subsection{Website Features for Usable Educational Websites}

This section reviews various studies that have contributed to the literature by identifying the relative importance of website features in the evaluation of usable educational websites from students' viewpoint. For example, Astani (2003) conducted a study that iden- 
tified the most, and least important features on a university website from the perspective of students. The results showed that the four most important features were: Online admission applications, search tools, simple and clear text, and resources. However, the four least important features were related to the inclusion of the site to: A site's purpose statement, school history of excellence, major local business and interests, and a link to the region's weather.

Similarly, Sandvig and Bajwa (2004) investigated the most liked and disliked website features by 48 students on nine university websites. The results showed that the most liked features were: Simple layout, useful information, good use of graphics and color, simple and comprehensive menu, well organized information, ease to navigate, and user-friendly. However, the least liked features were: Outdated links, incomplete and outdated information, confusing menus, inability to find information, cluttered and disorganized information, slow download time, and small fonts.

Alternatively, Guilikson et al. (1999) asked 24 students from six faculties to find the answers of six questions on a university website. The results showed that the participants found the answers to only 62 percentages of the questions. Guilikson et al. (1999) identified the reasons in their study, behind the inability of students to find information, which mainly related to: Unclear organization of the site's information, lack of a search engine, confusing menus, and poor navigational capabilities.

Regarding Arabic websites, only one study was found, which was conducted by Hasan (2012b). She investigated the relative importance of usability criteria in the evaluation of the usability of educational websites from the viewpoint of 237 students. The criteria consist of 25 website features distributed into five categories: Navigation, organization / architecture, ease of use and communications, design, and content. The results showed that the order of the criteria from the most to the least important in the evaluation of the usability of educational websites was: Content, navigation, ease of use and communications, design, and organization / architecture. The results also showed the website features, which students preferred the most for a usable educational website. These include: Navigation support, logical structure of a site, quick downloading of web pages, aesthetic design, and up-to date information.

The literature outlines above proved the usefulness of the heuristic evaluation method regarding its ability to identify various types of usability problems on educational websites. They provide important information regarding types of usability problem that could be found on educational websites. However, nearly all the studies, which employed the heuristic evaluation method, used quantitative data based on questionnaires to identify usability problems on the tested educational websites from the evaluators' point of view. Therefore, few number of usability problems, with little details, were provided.

The literature also summarizes studies, which employed users in the identification of usability problems on educational websites, and other studies which investigated the relative importance of website features, from student's viewpoint, in the evaluation of usable educational websites. These studies are a valuable source of usability problems that were identified, and perceived by students on various educational websites. 


\section{Methodology}

In order to select three Jordanian university websites, one of the major international university ranking websites was used; this was Eduroute (Eduroute, 2011). The three universities, which had the highest ranking, as provided by Eduroute for the year 2011, were selected as the sample for this research. The universities were: Hashemite University, the University of Jordan, and Yarmouk University. These universities are large public universities with a variety of disciplines. Hashemite University was established in 1991, the University of Jordan was established in 1962, while Yarmouk University was established in 1976.

In order to evaluate the usability of the selected university websites using the heuristic evaluation method, two documents were developed: Heuristic guidelines, and a list of tasks. The heuristic guidelines document includes a set of comprehensive heuristics, specific to educational websites, which was developed earlier by Hasan (2012a; 2012b), and used as criteria in the evaluation of educational websites in Jordan. The adopted heuristics were organized into five major categories. Table 1 displays the categories, and subcategories of the adopted heuristics.

The list of tasks document includes ten tasks, which represent pages students visit usually on a university website. These pages represent the findings obtained from an analysis of a questionnaire, which aimed to investigate the types of pages visited by students on a university website. The questionnaire was given to undergraduate students from various faculties at one of the universities in Jordan. The total number of students who provided usable responses was 237; 149 males, and 88 females. The participant students were in general experienced computer, and web users; $91 \%$ had more than three years of computer experience, and $75 \%$ had used the Internet for more than three years. The 237

Table 1

The categories and subcategories of the adopted heuristic guidelines

\begin{tabular}{ll}
\hline Category & Subcategories \\
\hline Navigation & $\begin{array}{l}\text { Navigation support; effective internal search; working links; no broken links; } \\
\text { no orphan pages. }\end{array}$ \\
Architecture/organization & Logical structure of site; no deep architecture; simple navigation menu. \\
Ease of use and & Quick downloading of web pages; easy interaction with a website; contact \\
communication & us information; foreign language support. \\
Design & $\begin{array}{l}\text { Aesthetic design (e.g. the site is attractive, appealing, and has professional } \\
\text { first impression); appropriate use of images; appropriate choice of fonts } \\
\text { (e.g. it is recommended to use bold text to highlight important text, and } \\
\text { capital letters for entire words and sentences, while the use of italics } \\
\text { are not recommended, also flashing or blinking text should be avoided } \\
\text { (Oppenheim and Ward, 2006)); appropriate choice of colors (e.g. no more } \\
\text { than three colors should be used for the body of text, and no more than two } \\
\text { should be used for the heading text (Ivory, 2003); appropriate page design; } \\
\text { consistency. }\end{array}$
\end{tabular}


students listed a total of 540 pages. The pages they specified are summarized in Table 2 . For example, the available courses page was the most frequently visited page listed by the students $(21.11 \%)$. Five pages listed only once or twice, and are counted in Table 2 under 'Others'. These pages include: Photo album, annual book, university newspaper, university conferences, and library.

Five evaluators participated in this research; two usability specialists, and three web experts. The evaluators were asked to visit all pages included in the list of tasks, and to use the heuristic guidelines while evaluating each website. They were also asked to visit all pages related to all faculties, and their corresponding departments on each of the studied universities' websites. The evaluation was done independently by each evaluator, and completed over four months (May 2012 to August 2012).

The heuristic evaluators' comments on the compliance of each site to each heuristic principle were grouped together for each site, and categorized under the categories and sub-categories of the heuristic guidelines. Each heuristic sub-category of each website was examined to identify problems with each site. These problems were classified, and similar problems were grouped together to identify common areas of usability problems on each website. These were examined to identify common areas of usability problems across the three websites. Consequently, 34 common areas of usability problems were identified, which suggested identifying 34 problem sub-themes. These 34 problem subthemes suggested identifying four main problem themes, based on the types of the identified problems. The four main problem themes related to: Navigation, design, content, and ease of use and communication. The list of problem themes and sub-themes is explained in the results, and shown in the Appendix.

The identified problems were categorized into three levels in terms of their location on the websites. The first level is 'university', and includes pages related directly to the main university website, such as: Academic calendar, university services, and pages related to

Table 2

Type of pages visited by students on a university website

\begin{tabular}{lrr}
\hline Pages Listed by Students & Frequency* & Percentage \\
\hline Academic calendar & 31 & $5.74 \%$ \\
Academic staff & 29 & $5.37 \%$ \\
Available courses & 114 & $21.11 \%$ \\
Deanship of student affairs- activities & 7 & $1.30 \%$ \\
Departments & 80 & $14.81 \%$ \\
Faculties & 80 & $14.81 \%$ \\
Others & 9 & $1.67 \%$ \\
Registration unit & 79 & $14.63 \%$ \\
Student services & 22 & $4.07 \%$ \\
Study plans & 44 & $8.15 \%$ \\
University announcements / news & 45 & $8.33 \%$ \\
\hline Total & $\mathbf{5 4 0}$ & $\mathbf{1 0 0 . 0 0 \%}$ \\
\hline
\end{tabular}

*Frequency: how often the page was mentioned by the participant students in the questionnaires. 
the registration unit. The second level is 'faculty', and includes all pages related to a faculty sub-site. The third level is 'department', and includes pages related to a department sub-site. The frequency number of the 34 specific usability problems, with regards to the three levels, was described for each of the tested website, as shown in the Appendix.

In order to determine the level of usability of the three studied university websites, and because of the fact that not all the university pages were investigated, a usability index was identified in this research, and calculated for the three websites. The usability index represents the number of usability problems found on a website, divided by the average number of pages investigated on the site.

\section{Results}

This section includes five sub-sections. The first presents a simple general comparison of usability of the three Jordanian university websites. The other four sub-sections explain, with regards to the four main problem themes, the type and number of specific usability problems identified on the sites.

\subsection{Usability of Jordanian University Websites}

The results show that all the tested websites had a large number of usability problems, as shown in Table 3. The results show that the website of Hashemite University has the lowest usability index compared to the other tested websites, indicating that it has the lowest number of usability problems per investigated pages, while the website of Yarmouk University has the highest usability index, indicating that it has the highest number of usability problems per investigated pages.

The usability index for the three tested websites, with regards to the four main usability problem themes, was calculated. Fig. 1 shows that Hashemite University website has the lowest usability index, with regard to the design area compared to the other two websites, while the University of Jordan website has the highest usability index in this area. This indicates that Hashemite University website has the lowest number of design problems per investigated pages, compared to the other two websites, while the University of Jordan website has the highest number of design problems.

Fig. 1 also shows that the University of Jordan website has the lowest usability index, with regard to two areas: Navigation and content, indicating that it has the lowest number

Table 3

The usability index for the websites

\begin{tabular}{lclc}
\hline & Hashemite University & The University of Jordan & Yarmouk University \\
\hline No. of Usability Problems & 4176 & 2926 & 3399 \\
No. of Pages Investigated & 1875 & 1129 & 1187 \\
Usability Index & 2.23 & 2.59 & 2.86 \\
\hline
\end{tabular}




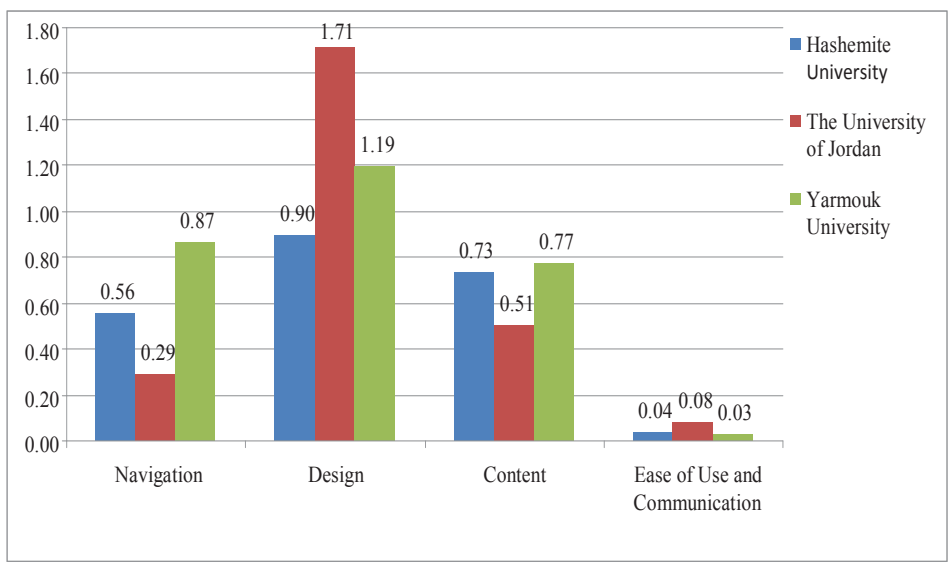

Fig. 1. The usability index for the three websites, with regard to the four identified usability areas.

of navigational and content problems, compared to the other two websites. The results, however, show that Yarmouk University website has the lowest usability index, with regard to the ease of use, and communication problems, compared to the other websites, indicating that this website has the lowest usability problems in this area.

Fig. 2 shows the percentages of the types of usability problems that were identified on the three websites, with regard to the four main usability problem themes. It shows that the highest percentage of the usability problems that were identified on each site is related to the design area, while the lowest percentage of the usability problems that were found on each site is related to the ease of use and communication area. Fig. 2 also shows that the second highest percentage of the usability problems identified on the websites of Hashemite University and the University of Jordan is related to the content area. However, the second highest percentage of usability problems identified on the website of Yarmouk University is related to the navigation area.

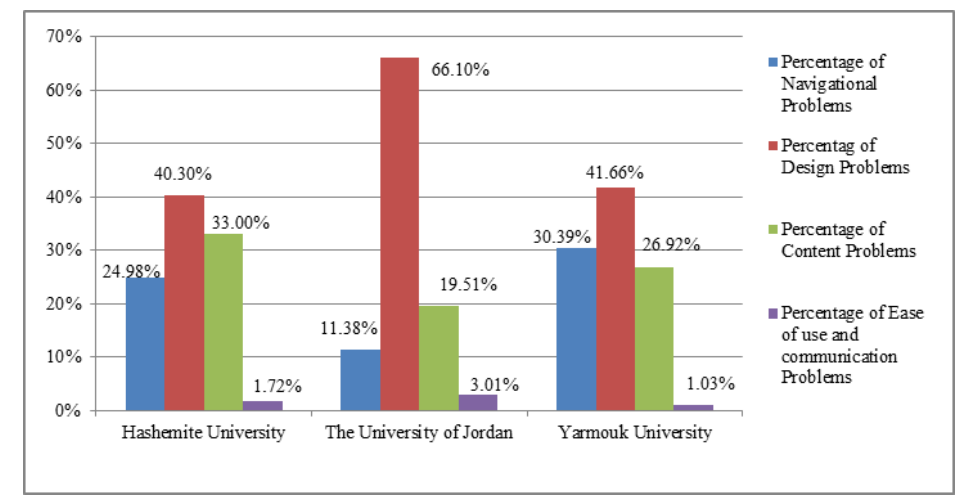

Fig. 2. The distribution of the types of usability problems identified on the three websites, with regards to the four main usability themes. 


\subsection{Navigational Problems}

Seven common navigational problems were identified on the selected Jordanian university websites, as shown in Table 4:

- The first problem is related to weak navigational support. Large numbers of this problem were identified on the websites of Hashemite University, and Yarmouk University. These concerned mainly with pages on the websites, related specifically to various faculties and/or departments, which did not have a navigational menu, or links to return back to the corresponding faculty and/or department (e.g. programs, student curriculum, and guidance plan pages, which related to all the departments of Hashemite University). The Appendix shows the frequency of this problem on the three websites, with regard to the three levels.

- The second problem is concerned with misleading links, where large numbers of such problem were found on the websites of Hashemite University and Yarmouk University. For example, the link related to the name of the chairman (for all the departments of Hashemite University) opened a page that was not expected by the evaluators; it opened a page that displays an introduction to the department instead of information about the chairman of the department.

- The third problem is related to links that do not open the destination pages. For example, the admission and research link, which was located at the home page of some faculties of Hashemite University, don't open the corresponding destination pages. They remain on the same page (the home page).

- The fourth problem is related to links, which when selected, caused the disappearance of the main menu or part of it. For example, selecting the back to top link (at the introduction page of Yarmouk University website), caused the disappearance of the corresponding department menu.

- The fifth problem is related to broken links. It was found that the website of Hashemite University had the largest number of this problem, compared to the other websites, on pages related to its faculties and departments (Appendix). For example, the class schedule link, which was located at the home page of all the faculties of Hashemite University website was broken.

Table 4

Common usability problem sub-themes related to navigation

\begin{tabular}{lccc}
\hline Navigational Problems & $\begin{array}{l}\text { Hashemite } \\
\text { University }\end{array}$ & $\begin{array}{l}\text { The University } \\
\text { of Jordan }\end{array}$ & $\begin{array}{c}\text { Yarmouk } \\
\text { University }\end{array}$ \\
\hline 1. Weak navigational support & 278 & 17 & 333 \\
2. Misleading links & 172 & 49 & 342 \\
3. Links do not open the destination pages & 46 & 20 & 75 \\
4. Links cause disappearance of the menu & 0 & 29 & 36 \\
5. Broken links & 529 & 208 & 21 \\
6. Orphan pages & 15 & 6 & 220 \\
7. Ineffective internal search & 3 & $\mathbf{3 3 3}$ & 6 \\
\hline Total no. of navigational problems & $\mathbf{1 0 4 3}$ & & $\mathbf{1 0 3 3}$ \\
\hline
\end{tabular}


- The sixth problem is related to orphan pages. The results showed that the website of Yarmouk University had the largest number of such problem, compared to the other websites, on pages related to its departments (Appendix). For example, the links related to the names of the faculty members, located at the faculty members page for all the departments of Yarmouk University, opened orphan pages.

- The seventh problem is concerned with ineffective internal search. The results showed that all the websites had problems with the internal search functions, related to the different universities' sub sites investigated during this research.

\subsection{Design Problems}

18 usability problems were identified on the Jordanian university websites regarding design, as shown in Table 5. Those problems concerned four major issues: Inconsistency (problems no. 1-9); inappropriate page design (problems no. 10-15); problems with the use of images (problems no. 16-17), and problems with the choice of colors (problem no. 18). It is worth mentioing that in this research all the inconsistency problems that were identified on the sites were categorized under the inconsistency sub-category eventhough some of them were not related to the design of the sites (e.g. inconsistency in the language of the interface and inconsistency in the content). The four major issues related the design problems:

Table 5

Common usability problem sub-themes related to design

\begin{tabular}{|c|c|c|c|}
\hline Design Problems & $\begin{array}{l}\text { Hashemite } \\
\text { University }\end{array}$ & $\begin{array}{l}\text { The University } \\
\text { of Jordan }\end{array}$ & $\begin{array}{l}\text { Yarmouk } \\
\text { University }\end{array}$ \\
\hline 1. Inconsistency in the language of the interface & 140 & 138 & 109 \\
\hline 2. Inconsistency in the font case (capital and small) & 163 & 76 & 6 \\
\hline 3. Inconsistency in the font size & 19 & 50 & 84 \\
\hline 4. Inconsistency in the font style (regular and bold) & 59 & 18 & 76 \\
\hline 5. Inconsistency in the content & 10 & 28 & 15 \\
\hline 6. Inconsistency in the alignment of the header & 2 & 19 & 4 \\
\hline 7. Inconsistency in the font color & 13 & 31 & 0 \\
\hline 8. Inconsistency in the design & 12 & 0 & 0 \\
\hline 9. Inconsistency in the size of images & 0 & 0 & 52 \\
\hline 10. Inappropriate orientation of the page design & 60 & 0 & 179 \\
\hline 11. Inappropriate design of main menu & 39 & 101 & 113 \\
\hline 12. Ineffective text format & 925 & 457 & 427 \\
\hline 13. Inappropriate/ not representative heading of a page & 95 & 432 & 142 \\
\hline 14. Long pages & 2 & 5 & 149 \\
\hline 15. Short pages & 0 & 0 & 29 \\
\hline 16. Inappropriate quality of images & 57 & 19 & 29 \\
\hline 17. Broken images & 30 & 532 & 2 \\
\hline 18. Inappropriate choice of color & 57 & 28 & 0 \\
\hline Total no. of design problems & 1683 & 1934 & 1416 \\
\hline
\end{tabular}


- Nine specific inconsistency problems were identified on the websites (Table 5, problems no. 1-9). The results revealed that the large number of the inconsistency problems that was found on the sites related to inconsistency in the language of the interface. This is related to links at the English interface of a site, which opened pages that displayed Arabic content, and vice versa. Other examples of inconsistency problems are shown in Table 5.

- Six problems were found on the sites concerned inappropriate design of their pages (Table 5, problems no. 10-15). One of theses problems related to ineffective text format of the sites' pages, where information, figures, and tables were not aligned correctly. The results showed that all the websites had large number of such problems (Table 5, Appendix). Another problem, which was commonly identified on the websites of Hashemite University and Yarmouk University, related to inappropriate orientation of the page design. For example, it was found that the main menu and the vertical scrollbar, for all the faculties at the English language interface of Yarmouk University website, were located at the right side of the page instead of the left side. Table 5 also shows that the University of Jordan website had many pages without headings or with inappropriate headings.

- Another two specific types of problems were found on the sites related to inappropriate use of images: Poor quality of images, and broken images (Table 5, problems no. 16-17). Table 5 shows that the University of Jordan website had the largest number of broken images, compared to the other sites, on pages related to its faculties and departments (Appendix). For example, message from the dean and photo gallery pages for most of the faculties of the University of Jordan website had broken images.

- The last problem is related to inappropriate choice of color, and was identified on Hashemite University, and the University of Jordan websites (Table 5, problem no. 18). These websites have pages that used inappropriate combination of background and font colors.

\subsection{Content Problems}

Seven common usability problems were identified on the Jordanian university websites regarding content, as shown in Table 6:

- The first problem is related to old information, which was presented on pages related to various faculties and departments of Hashemite University and the University of Jordan websites (Appendix). Examples on these pages: Latest news and activities on Hashemite University website.

- The second problem is related to incomplete information. The results show that all the websites had large number of such problem (e.g. faculty staff pages on Hashemite University).

- Regarding the third problem, the results show that the websites of Hashemite University and Yarmouk University had pages with links that open DOC and/or PDF files, but there is no information regarding the type of file a link opened. 
Table 6

Common usability problem sub-themes related to content

\begin{tabular}{lccc}
\hline Content Problems & $\begin{array}{l}\text { Hashemite } \\
\text { University }\end{array}$ & $\begin{array}{l}\text { The University } \\
\text { of Jordan }\end{array}$ & $\begin{array}{l}\text { Yarmouk } \\
\text { University }\end{array}$ \\
\hline 1. Old information & 68 & 41 & 0 \\
2. Incomplete information & 344 & 158 & 463 \\
3. No information regarding the type & 59 & 0 & 227 \\
$\quad$ of a file that a link will open & 173 & 242 & 148 \\
4. Empty page & 444 & 80 & 62 \\
5. Inappropriate content & 272 & 39 & 13 \\
6. Punctuation errors & 18 & 11 & 2 \\
7. Grammatical accuracy problems & $\mathbf{1 3 7 8}$ & $\mathbf{5 7 1}$ & $\mathbf{9 1 5}$ \\
\hline Total no. of content problems & & & \\
\hline
\end{tabular}

- The fourth problem is related to empty pages, where the University of Jordan website had the largest number of this problem, compared to the other two websites.

- With regard to the fifth problem, the results showed that all the sites had inappropriate content problems. Examples on these problems: Crowded pages, repetition of content, and very concise content.

- Finally, the results identified two specific types of problems related to grammatical accuracy: Punctuation and grammatical errors (the sixth and seventh problems at Table 6, respectively). An example on pages with spelling errors, which related to the University of Jordan website, is the vision and mission page, on the Faculty of Arts and design, where there was a spelling error in its header; vission was written instead of vision.

\subsection{Ease of Use and Communication Problems}

Two usability problems were identified on the Jordanian university websites regarding ease of use and communication, as shown in Table 7:

- The first problem is related to being not easy to interact with the websites, in order to visit some pages. For example, it was not easy to visit the Occupational Therapy Department from the corresponding faculty website (Allied Health Science related

Table 7

Common usability problem sub-themes related to ease of use and communication

\begin{tabular}{lccc}
\hline Ease of Use and Communication Problems & $\begin{array}{l}\text { Hashemite } \\
\text { University }\end{array}$ & $\begin{array}{l}\text { The University } \\
\text { of Jordan }\end{array}$ & $\begin{array}{l}\text { Yarmouk } \\
\text { University }\end{array}$ \\
\hline Difficult interaction with a website & 8 & 3 & 35 \\
Not supporting more than one language & 64 & 85 & 0 \\
\hline Total no. of ease of use and communication problems & $\mathbf{7 2}$ & $\mathbf{8 8}$ & $\mathbf{3 5}$ \\
\hline
\end{tabular}


to Hashemite University), since the faculty main menu did not have an item for it. The only way to visit the department was from the university main menu.

- The second problem is related to the lack of support to the Arabic language. The results show that the websites of Hashemite University and the University of Jordan had problems related to the fact that they did not support the Arabic language. The language interface of the Hashemite University website, including its 13 faculties and their corresponding departments, was written only in English language. Regarding the University of Jordan website, it was found that most of its faculties (16 out of 18) and their corresponding departments were presented using only English language. However, Yarmouk University website presents the university faculties and their corresponding departments using Arabic and English languages.

\section{Discussion}

This research addressed a gap noted in the literature, with regard to lack of identification of specific types of usability problems found by heuristic evaluation methods on educational websites, specifically in Jordan. Earlier research, which evaluated the usability of educational websites, provided only few examples of the usability problems that were identified by the heuristic evaluation method (Astani and Elhindi, 2008; Noiwan and Norcio, 2000; Pierce, 2005; Kostaras and Xenos, 2006; Toit and Bothma, 2010). This could relate to the fact that in these studies the usability problems that were identified by the heuristic evaluators were only based on the quantitative data obtained from various methods used in their research. This research, however, uniquely identified large number of usability problems, related to 34 specific types of usability problems that could be found on an educational website. It also presented the frequency number of these problems on each of the tested website (Appendix). This is related to the fact that this research used the qualitative data obtained from the heuristic evaluators, who comprehensively investigated large number of pages on the three selected Jordanian university websites, in the process of identifying the usability problems.

Despite the fact that the results of this research involved providing more detailed descriptions of usability problems that were identified by the heuristic evaluation compared to the previous research, it was found that there was an agreement between the results of this research, and the results of the previous studies. Table 8 summarizes the usability problems, which were identified by the heuristic evaluators on educational websites, by earlier research.

These were also confirmed by the results of this research. Specific examples of problems identified in this research were discussed in Section four. The Appendix provides more information regarding the frequency of similar problems on the tested websites, and provides information regarding additional problems that were uniquely identified in this research. These included: Misleading links, links don't open the destination pages, links cause disappearance of the menu, broken links, various types of inconsistency problems, inappropriate orientation of the page design, ineffective text format, broken images, inappropriate choice of color, empty page, inappropriate content, difficult interaction with a website, and lack of support to the Arabic language. 
Table 8

Examples of usability problems identified by the heuristic evaluation method

\begin{tabular}{ll}
\hline Example of Usability Problems & References \\
\hline Old content & $\begin{array}{l}\text { Astani and Elhindi (2008); Noiwan and Norcio (2000); Toit and Bothma } \\
(2010)\end{array}$ \\
Lack of navigational support & $\begin{array}{l}\text { Noiwan and Norcio (2000); Kostaras and Xenos (2006); Toit and Bothma } \\
(2010) ; \text { Pierce (2005) }\end{array}$ \\
Inconsistency problems & Noiwan and Norcio (2000); Kostaras and Xenos (2006); Pierce (2005) \\
Ineffective internal search & Noiwan and Norcio (2000); Kostaras and Xenos (2006) \\
Language problems & Noiwan and Norcio (2000) \\
Inappropriate page design & Astani and Elhindi (2008); Pierce (2005) \\
Incomplete information & Toit and Bothma (2010) \\
Inappropriate design of menus & Kostaras and Xenos (2006) \\
\hline
\end{tabular}

The large number of common and specific usability problems that were uniquely identified in this research on the Jordanian universities' websites, could be used as guidelines for universities in Jordan, to investigate and improve their universities' websites, and therefore to achieve the advantages of usable educational websites.

This research, however, had two limitations. The first related to the fact that it employed only heuristic evaluators who identified large number of usability problems on the three universities' websites from the viewpoint of evaluators, and not users. The second related to the fact that the classification step of usability problems according to their severity (e.g. major and minor problems), from the point of view of the evaluators, could not be accomplished. This is related to the lack of evaluators' time to accomplish this task. Because of these limitations, a further step was taken. It aimed at shedding the light on some usability problems, among the 34 specific types of problems, which might be important from students' perspective. This was done by making a comparison between the 34 specific types of usability problems identified in this research, with the usability problems identified by users in earlier research (Section 2). Table 9 shows 17 (out of 34) types of usability problems that were identified in this research, which were also identified by users in earlier studies. These problems could be considered as important problems, and could be given greater weight, while improving the usability of Jordanian universities' websites.

\section{Conclusions}

This research comprehensively evaluated the usability of three large public university websites in Jordan, namely: Hashemite University, the University of Jordan, and Yarmouk University, including all pages related to their faculties and departments, using the heuristic evaluation method. The results identified a list of 34 specific types of common usability problems that were found on the selected Jordanian university websites, and described the frequency number of these problems, and their locations on the websites. 
Table 9

Usability problems identified in this research and usability problems identified by users in earlier research

\begin{tabular}{|c|c|}
\hline Usability problems identified in this research & Usability Problems identified by users \\
\hline Weak navigation support & Poor navigational capabilities (Guilikson et al., 1999) \\
\hline Ineffective Internal search & Ineffective search function (Christoun et al., 2006) \\
\hline $\begin{array}{l}\text { Inconsistency in the language of the interface } \\
\text { Inconsistency in font case (capital and small) } \\
\text { Inconsistency in the font size } \\
\text { Inconsistency in the font style (regular and bold) } \\
\text { Inconsistency in the content } \\
\text { Inconsistency in the alignment of the header } \\
\text { Inconsistency in the font color } \\
\text { Inconsistency in the design } \\
\text { Inconsistency in the size of images }\end{array}$ & $\begin{array}{l}\text { Inconsistency (colors, fonts, Arabic and English } \\
\text { language interface, design of the pages) (Hasan, } \\
\text { 2012a) }\end{array}$ \\
\hline Inappropriate design of main menu & $\begin{array}{l}\text { Confusing menus (Sandvig and Bajwa, 2004; Guilikson } \\
\text { et al., 1999) }\end{array}$ \\
\hline Old information & $\begin{array}{l}\text { Old content (Kasli and Aucikurt, 2008; Sandvig and } \\
\text { Bajwa, 2004; Hasan, 2012a) }\end{array}$ \\
\hline Incomplete information & $\begin{array}{l}\text { Missing information (Kasli and Aucikurt, 2008; } \\
\text { Sandvig and Bajwa, 2004) }\end{array}$ \\
\hline Inappropriate content & $\begin{array}{l}\text { Cluttered and disorganized information (Sandvig and } \\
\text { Bajwa, 2004) }\end{array}$ \\
\hline Difficult interaction with a website & $\begin{array}{l}\text { Not easy to find information (Christoun et al., 2006; } \\
\text { Sandvig and Bajwa, 2004) }\end{array}$ \\
\hline Not supporting more than one language & Lack of support for the Arabic language (Hasan, 2012a) \\
\hline
\end{tabular}

The results of this research illustrated the effectiveness of the heuristic evaluation method in identifying a large number of usability problems that could be used to improve different aspects of universities' websites. The large number of usability problems, identified by the evaluators, could be also identified using software tools (e.g. HTML Toolbox), which automatically assess whether a website conform to a set of specific guidelines. The software tools, however, assess the quality of the HTML code of a website with regards to a number of guidelines, which focus on the accessibility of a site rather than its general usability. Furthermore, the results provided by such tools do not provide sufficient details regarding types of problems on a website. Unlike software tools, the heuristic evaluation method provided details regarding specific types of usability problems that were found by the evaluators on the websites.

The results of this research emphasized the limitations of the heuristic evaluation, with regard to the fact that the heuristic evaluators could not play the role of real users, and could not predict actual problems that users might face while interacting with the sites. Therefore, a further step was taken. This is related to comparing the 34 usability problems with earlier studies that identified usability problems on educational sites from 
the point view of students. The results shed the light on some usability problems (17 out of 34), which might be major for students. These problems related to: Lack of navigational support, ineffective internal search, inconsistency problems, inappropriate design of main menu, old information, incomplete information, difficult interaction with a website, and lack of support to the Arabic language.

The results are particularly useful for managers, designers, and/or evaluators of universities' websites in Jordan, who are willing to evaluate and improve the design of their websites in order to reap the advantages of usable educational websites. The 34 specific types of common usability problems that were identified in this research provide guidance for them regarding website features, which should be taken into consideration while designing and/or evaluating educational websites.

\section{References}

Agarwal, R., Venkatesh, V. (2002). Assessing a firm's web presence: a heuristic evaluation procedure for the measurement of usability. Information Systems Research, 13(2), 168-186.

Astani, M. (2003). An empirical study of the effectiveness of universities' web sites. Issues in Information Systems, 4, 14-20.

Astani, M., Elhindi, M. (2008). An empirical study of university websites. Issues in Information Systems, IX(2), $460-465$.

Christoun, S., Aubin, H., Hannon, C., Wolk, R. (2006). Web site usability in higher education. Information Systems Education Journal, 4(110).

Eduroute (2011). http: / / www .eduroute.info

Hasan, L. (2012a). Evaluating the usability of nine Jordanian university websites. In: Proceedings of the $2^{\text {nd }}$ International Conference on Communications and Information Technology (ICCIT). Hammamet, Tunisia, $102-107$.

Hasan, L. (2012a). Investigating the relative importance of design criteria in the evaluation of the usability of educational websites from the viewpoint of students. In: Proceedings of the World Congress on Engineering (WCE 2012). London.

Ivory, M. (2003). Automated Web Site Evaluation: Researchers'and Practitioners'Perspectives. Kluwer Academic Publishers, London.

ISO 9241-11, International Standard First Edition. Ergonomic Requirements for Office Work with Visual Display Terminals (VDTs), Part11: Guidance on Usability, (1998).

http://www.idemployee.id.tue.nl/g.w.m.rauterberg/lecturenotes/Iso9241part11. pdf

Kasli, M., Avcikurt, C. (2008). An investigation to evaluate the websites of tourism departments of universities in Turkey. Journal of Hospitality, Leisure, Sport \& Tourism Education, 7(2), 77-92.

Kostaras, N., Xenos, M. (2006). Assessing educational web-site usability using heuristic evaluation rules. In: Proceedings of 11th Panhellenic Conference in Informatics.

Lencastre, J., Chaves, J. (2008). A usability evaluation of educational websites. In: Proceedings of EADTU Conference.

Mentes, A., Turan, A. (2012). Assessing the usability of university websites: an empirical study on Namic Kemal University. The Turkish Online Journal of Educational Technology, 11(3), 61-69.

Mustafa, S., Al-Zoua'bi, L. (2008). Usability of the academic websites of Jordan's universities. In: Proceedings of the International Arab Conference on Information Technology. Tunisia.

Nielsen, J., Molich, R. (1990). Heuristic evaluation of user interfaces. In: Proceedings of CHI'90, ACM, 249-256.

Nielsen, J. (1994). Heuristic evaluation, In: Nielsen J. \& Mack R. L. (Eds.), Usability Inspection Methods. John Wiley \& Sons, New York, 25-64.

Nielsen, J. (2003). Usability 101: Introduction to usability. Useit.com. http://www.useit.com/alertbox/20030825.html

Noiwan, J., Norcio, A. (2000). A comparison analysis on web heuristic usability between Thai academic web 
sites and US academic web sites. In: Proceedings of SGI, World Multi Conference on Systems, Cybermetrics and Informatics. Concepts and Applications of Systems, Cybermetrics and Informatics, Orlando, Florida, USA, 536-541.

Oppenheim, C., Ward, L. (2006). Evaluation of websites for B2C e-commerce. Aslib Proceedings: New Information Perspectives, 58(3), 237-260.

Peterson, K. (2006). Academic web site design and academic templates: where does the library fit. Information Technology and Libraries, 25(4), 217-221.

Pierce, K. (2005). Web site usability report for Harvard university. Technical Report. Capella University.

Sandvig, J., Bajwa, D. (2004). Information seeking on university web sites: an exploratory study. Journal of Computer Information Systems, 25(1), 13-22.

Toit, M., Bothma, C. (2010). Evaluating the usability of an academic marketing department's website from a marketing student's perspective. International Retail and Marketing Review, 5(1), 15-24.

\section{Appendix}

Usability problem themes and sub-theme identified in this research, together with the number of each problem on each of the tested website with regard to the three levels.

\section{Hashemite University The University of Yarmouk University Jordan}

\section{Navigational Problems}

1. Weak navigational support

Freq. $\quad$ Freq. $\quad$ Freq.

2. Misleading links

$\begin{array}{llllllllllll}\text { U } & \text { F } & \text { D } & \text { T } & \text { U } & \text { F } & \text { D } & \text { T } & \text { U } & \text { F } & \text { D } & \text { T } \\ 2 & 130 & 146 & \mathbf{2 7 8} & 4 & 10 & 3 & \mathbf{1 7} & 85 & 42 & 206 & \mathbf{3 3 3}\end{array}$

$$
\begin{array}{llllllllllllll}
\text { Freq. } & & & \text { Freq. } & & & \text { Freq. } & & \\
\text { U } & \text { F } & \text { D } & \text { T } & \text { U } & \text { F } & \text { D } & \text { T } & \text { U } & \text { F } & \text { D } & \text { T }
\end{array}
$$
3. Links do not open the destina-
tion pages

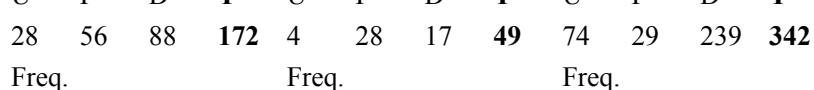

$$
\begin{array}{llllllllllll}
\mathrm{U} & \mathrm{F} & \mathrm{D} & \mathbf{T} & \mathrm{U} & \mathrm{F} & \mathrm{D} & \mathbf{T} & \mathrm{U} & \mathrm{F} & \mathrm{D} & \mathbf{T} \\
2 & 44 & 0 & \mathbf{4 6} & & 20 & 0 & \mathbf{2 0} & 1 & 16 & 58 & \mathbf{7 5}
\end{array}
$$

4. Links cause disappearance of the menu

$\begin{array}{llllllllllllll}0 & \text { U } & \text { F } & \text { D } & \text { T } & \text { U } & \text { F } & \text { D } & \text { T }\end{array}$

5. Broken links

Freq.

$\begin{array}{lllllll}4 & 22 & 3 & \mathbf{2 9} & 2 & 34 & \mathbf{3 6}\end{array}$

6. Orphan Pages

$\begin{array}{llllllllllll}\text { U } & \text { F } & \text { D } & \text { T } & \text { U } & \text { F } & \text { D } & \text { T } & \text { U } & \text { F } & \text { D } & \text { T } \\ 9 & 274 & 246 & \mathbf{5 2 9} & 3 & 74 & 131 & \mathbf{2 0 8} & 12 & 3 & 6 & \mathbf{2 1}\end{array}$

6. Orphan Pages

Freq. $\quad$ Freq. $\quad$ Freq

\begin{tabular}{llllllllllll} 
U & F & D & T & U & F & D & T & U & F & D & T \\
\hline & 13 & 0 & $\mathbf{1 5}$ & 2 & 4 & 0 & 6 & 0 & 2 & 218 & $\mathbf{2 2}$
\end{tabular}

7. Ineffective internal search Freq. $\quad$ Freq.

$\begin{array}{llllllllllll}\text { U } & \text { F } & \text { D } & \text { T } & \text { U } & \text { F } & \text { D } & \text { T } & \text { U } & \text { F } & \text { D } & \text { T } \\ 1 & 1 & 1 & \mathbf{3} & 2 & 1 & 1 & \mathbf{4} & 2 & 2 & 2 & 6\end{array}$

Total number of navigational problems

Freq.

Freq.$$
\begin{array}{llllllllllll}
\text { U } & \text { F } & \text { D } & \text { T } & \text { U } & \text { F } & \text { D } & \text { T } & \text { U } & \text { F } & \text { D } & \text { T } \\
44 & 518 & 481 & 1043 & 19 & 159 & 155 & 333 & 176 & 94 & 763 & 1033
\end{array}
$$ 


\section{Design Problems}

8. Inconsistency in the language of the interface

9. Inconsistency in font case (capital and small)

10. Inconsistency in the font size Freq.

Freq. $\quad$ Freq.

Freq.

$\begin{array}{llllllllllll}\text { U } & \text { F } & \text { D } & \text { T } & \text { U } & \text { F } & \text { D } & \text { T } & \text { U } & \text { F } & \text { D } & \text { T }\end{array}$

$\begin{array}{llllllllllll}13 & 45 & 82 & \mathbf{1 4 0} & 7 & 75 & 56 & \mathbf{1 3 8} & 37 & 1 & 71 & 109\end{array}$

Freq.

Freq.

Freq.

$\begin{array}{llllllllllll}\mathrm{U} & \mathrm{F} & \mathrm{D} & \mathbf{T} & \mathrm{U} & \mathrm{F} & \mathrm{D} & \mathbf{T} & \mathrm{U} & \mathrm{F} & \mathrm{D} & \mathbf{T} \\ 1 & 19 & 143 & \mathbf{1 6 3} & 0 & 20 & 56 & \mathbf{7 6} & 2 & 1 & 3 & \mathbf{6}\end{array}$

$\begin{array}{llllllllllll}\text { U } & \text { F } & \text { D } & \text { T } & \text { U } & \text { F } & \text { D } & \text { T } & \text { U } & \text { F } & \text { D } & \text { T } \\ 0 & 11 & 8 & \mathbf{1 9} & 0 & 15 & 35 & \mathbf{5 0} & 3 & 27 & 54 & \mathbf{8 4}\end{array}$

11. Inconsistency in the font Freq. style (regular and bold)

12. Inconsistency in the content Freq.

$\begin{array}{llllllllllll}\text { U } & \text { F } & \text { D } & \text { T } & \text { U } & \text { F } & \text { D } & \text { T } & \text { U } & \text { F } & \text { D } & \text { T }\end{array}$

$\begin{array}{llllllllllll}0 & 12 & 47 & \mathbf{5 9} & 0 & 7 & 11 & \mathbf{1 8} & 3 & 23 & 50 & \mathbf{7 6}\end{array}$

$$
\begin{array}{llllllllllll}
\mathrm{U} & \mathrm{F} & \mathrm{D} & \mathbf{T} & \mathrm{U} & \mathrm{F} & \mathrm{D} & \mathbf{T} & \mathrm{U} & \mathrm{F} & \mathrm{D} & \mathbf{T} \\
0 & 4 & 6 & \mathbf{1 0} & 1 & 17 & 10 & \mathbf{2 8} & 4 & 2 & 9 & \mathbf{1 5}
\end{array}
$$

13. Inconsistency in the align- Freq Freq. Freq. ment of the header

$\begin{array}{llllllllllll}\mathrm{U} & \mathrm{F} & \mathrm{D} & \mathbf{T} & \mathrm{U} & \mathrm{F} & \mathrm{D} & \mathbf{T} & \mathrm{U} & \mathrm{F} & \mathrm{D} & \mathbf{T} \\ 0 & 2 & 0 & \mathbf{2} & 0 & 4 & 15 & \mathbf{1 9} & 0 & 4 & 0 & \mathbf{4}\end{array}$

14. Inconsistency in the font Freq. Freq. color

$\begin{array}{llllllll}\mathrm{U} & \mathrm{F} & \mathrm{D} & \mathbf{T} & \mathrm{U} & \mathrm{F} & \mathrm{D} & \mathbf{T} \\ 0 & 8 & 5 & \mathbf{1 3} & 0 & 11 & 20 & \mathbf{3 1}\end{array}$

15. Inconsistency in the design Freq.

$\begin{array}{llll}\mathrm{U} & \mathrm{F} & \mathrm{D} & \mathrm{T} \\ 0 & 12 & 0 & \mathbf{1 2}\end{array}$

16. Inconsistency in the size of images

Freq.

17. Inappropriate orientation of the page design

Freq.

U F D $\quad$ T$$
\begin{array}{llll}
1 & 15 & 44 & \mathbf{6 0}
\end{array}
$$

18. Inappropriate design of main Freq. menu

Freq.

$\begin{array}{llll}\mathrm{U} & \mathrm{F} & \mathrm{D} & \mathbf{T} \\ 0 & 52 & 0 & \mathbf{5 2}\end{array}$

Freq.

U F $\quad$ D $\quad$ T

$\begin{array}{llll}7 & 29 & 143 & \mathbf{1 7 9}\end{array}$

Freq.

$$
\begin{array}{llllllllllll}
\mathrm{U} & \mathrm{F} & \mathrm{D} & \mathbf{T} & \mathrm{U} & \mathrm{F} & \mathrm{D} & \mathbf{T} & \mathrm{U} & \mathrm{F} & \mathrm{D} & \mathbf{T} \\
0 & 23 & 16 & \mathbf{3 9} & 0 & 41 & 60 & \mathbf{1 0 1} & 4 & 18 & 91 & \mathbf{1 1 3}
\end{array}
$$

19. Ineffective text format

$$
\text { Freq. } \quad \text { Freq. }
$$$$
\begin{array}{llllllllllllllll}
\mathrm{U} & \mathrm{F} & \mathrm{D} & \mathbf{T} & \mathrm{U} & \mathrm{F} & \mathrm{D} & \mathbf{T} & \mathrm{U} & \mathrm{F} & \mathrm{D} & \mathbf{T}
\end{array}
$$$$
\begin{array}{llllllllllll}
31 & 263 & 631 & \mathbf{9 2 5} & 0 & 110 & 347 & \mathbf{4 5 7} & 34 & 51 & 342 & \mathbf{4 2 7}
\end{array}
$$

20. Inappropriate/ not representa- Freq. Freq.

Freq. tive heading of a page

$$
\begin{array}{llllllllllll}
\mathrm{U} & \mathrm{F} & \mathrm{D} & \mathrm{T} & \mathrm{U} & \mathrm{F} & \mathrm{D} & \mathbf{T} & \mathrm{U} & \mathrm{F} & \mathrm{D} & \mathbf{T} \\
3 & 86 & 6 & \mathbf{9 5} & 2 & 145 & 285 & \mathbf{4 3 2} & 5 & 26 & 111 & \mathbf{1 4 2}
\end{array}
$$

21. Long pages

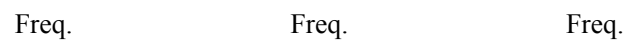




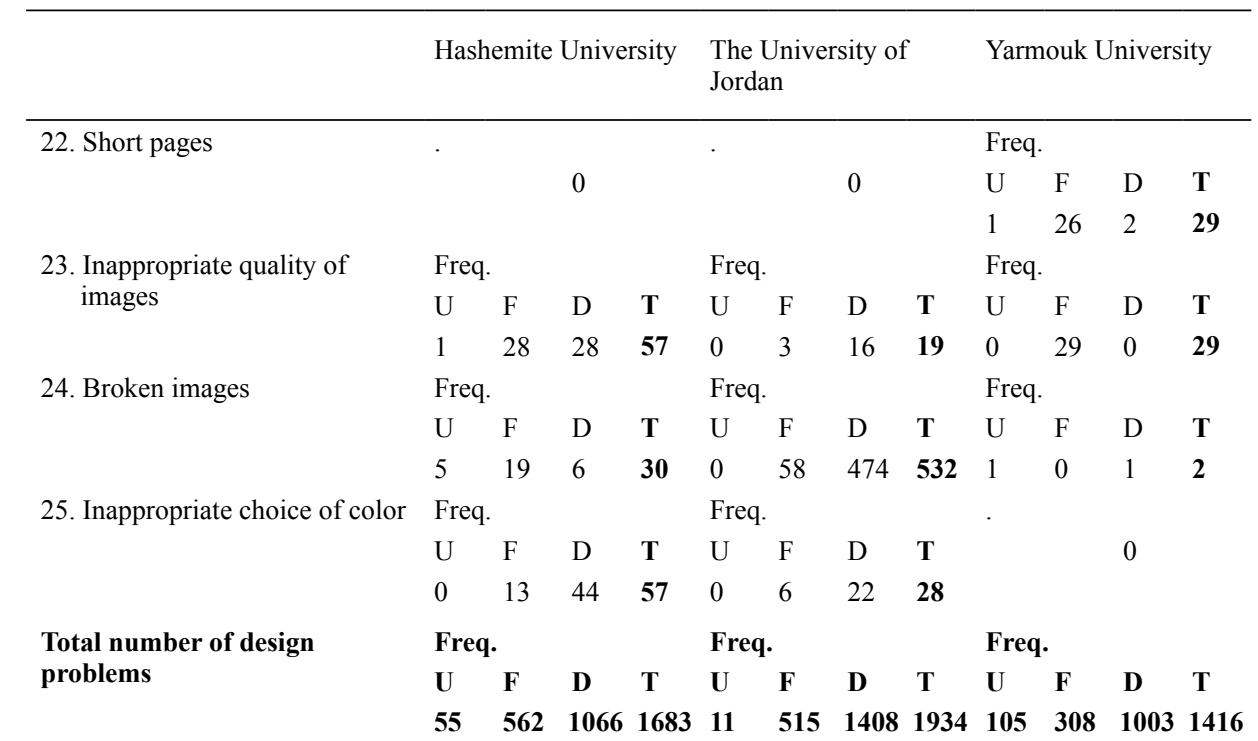

\section{Content Problems}

26. Old information

Freq. $\quad$ Freq.

$\begin{array}{lllllllllll} & 3 & 39 & 26 & \mathbf{6 8} & 1 & 37 & 3 & \mathbf{4 1} & \\ \text { 27. Incomplete information } & \text { Freq. } & & & \text { Freq. } & & & \text { Freq. }\end{array}$

$\begin{array}{lllllllll}\text { U } & \text { F } & \text { D } & \text { T } & \text { U } & \text { F } & \text { D } & \text { T } & 0 \\ 3 & 39 & 26 & \mathbf{6 8} & 1 & 37 & 3 & \mathbf{4 1} & \end{array}$

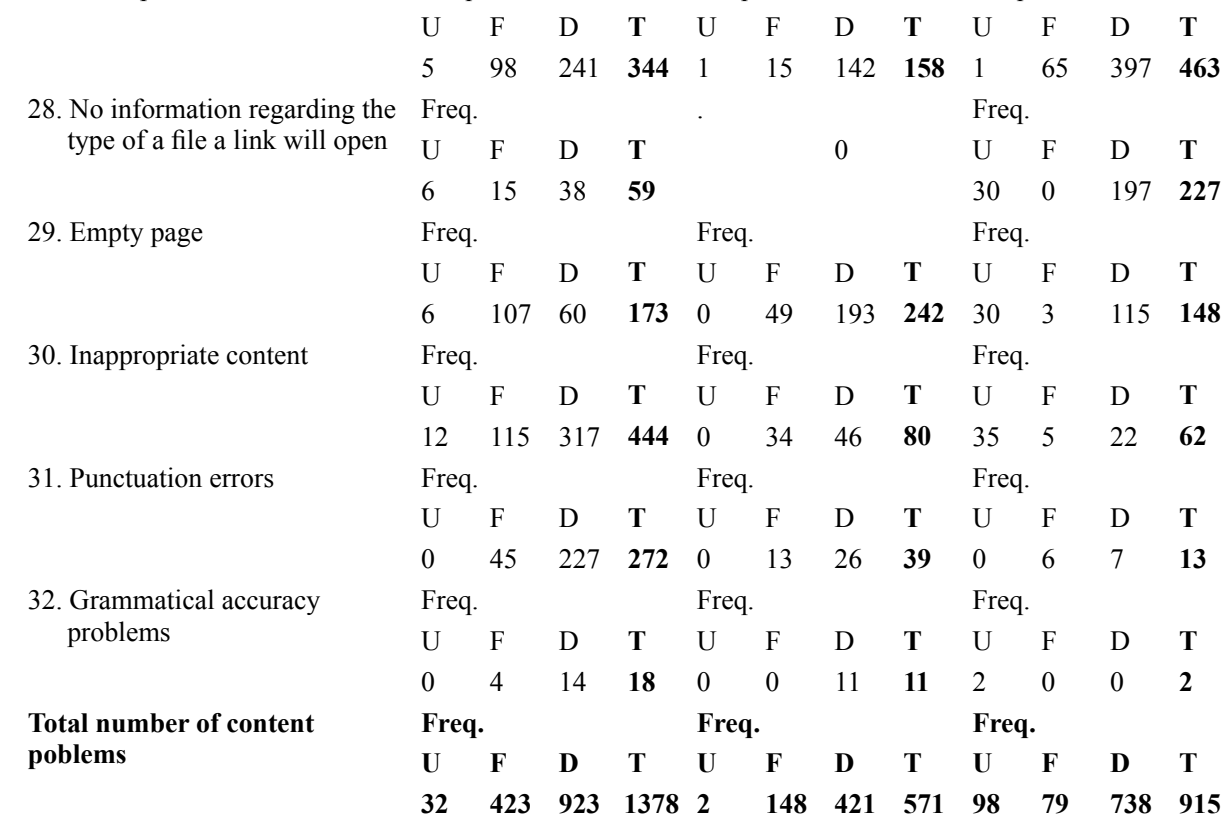




\title{
Hashemite University The University of Yarmouk University
} Jordan

\begin{abstract}
Ease of Use and Communication Problems
33. Difficult interaction with a website

Freq. $\quad$ Freq. $\quad$ Freq.

$\begin{array}{llllllllllll}\mathrm{U} & \mathrm{F} & \mathrm{D} & \mathbf{T} & \mathrm{U} & \mathrm{F} & \mathrm{D} & \mathbf{T} & \mathrm{U} & \mathrm{F} & \mathrm{D} & \mathbf{T}\end{array}$

$\begin{array}{llllllllllll}6 & 0 & 2 & \mathbf{8} & 3 & 0 & 0 & \mathbf{3} & 1 & 26 & 8 & \mathbf{3 5}\end{array}$

34. Not supporting more than one language

Freq. $\quad$ Freq.

$\begin{array}{lllllllll}\text { U } & \text { F } & \text { D } & \text { T } & \text { U } & \text { F } & \text { D } & \text { T } & 0\end{array}$

$\begin{array}{lllllll}7 & 13 & 44 & \mathbf{4 6} & 14 & 71 & \mathbf{8 5}\end{array}$

Total number of ease of use

Freq.

Freq. $\quad$ Freq.

$\begin{array}{llllllllllllll}\text { and communication problems } & \mathbf{U} & \mathbf{F} & \mathbf{D} & \mathbf{T} & \mathbf{U} & \mathbf{F} & \mathbf{D} & \mathbf{T} & \mathbf{U} & \mathbf{F} & \mathbf{D} & \mathbf{T}\end{array}$

$\begin{array}{llllllllllll}13 & 13 & 46 & 72 & 3 & 14 & 71 & 88 & 1 & 26 & 8 & 35\end{array}$

Freq.: Frequency of the problem

U: University level

D: Department level

F: Faculty level

T: Total no. of problems for the problem sub-theme

L. Hasan is an assistant professor in the Department of Computer Information Systems, Zarqa University, Jordan. She holds a BSc degree in computer science from the University of Jordan, Jordan in 1996; an MBA degree in business administration from the University of Jordan, Jordan in 2004; and a PhD degree in computer science from the Loughborough University, UK in 2009. Her research interests include web-based human computer interaction, website usability methods, web analytics, and website quality.
\end{abstract}

\section{Trijų Jordanijos universitetų svetainių euristinis vertinimas}

\section{Layla HASAN}

Dažniausiai universitetai turi dideles kompleksines svetaines, apimančias kitas svetaines susietas su skirtingomis universiteto atliekamomis funkcijomis (pvz., registracijos svetainė, fakultetų, katedrų svetainès). Akademinių institucijų ir edukacinių svetainių vadovai turi žinoti iškylančių svetainių naudojimo problemų grupes. Problemų išaiškinimas turètų padèti surasti svetainių trūkumus, kuriuos pašalinus būtų pasiektas efektyvesnis edukacinių svetainių naudojimas. Pastebėta tyrimų, skirtų svetainių naudojimo problemoms, tipų analizès stoka. Tyrime taikomas euristinis vertinimo metodas, kuriuo siekiama įvertinti trijų didžiųų Jordanijos universitetų (Hashemite, Jordanijos ir Yarmouk universiteto) svetainių naudojimą. Vertinimas apima visų tinklalapių, susietų su atrinktais universitetų fakultetais ir atitinkamomis katedromis testavimą. Nustatyti 34 Jordanijos universitetų svetainėse rasti jų naudojimo problemų tipai. Pateikiami rastų tipų aprašai su konkrečiais pavyzdžiais. 